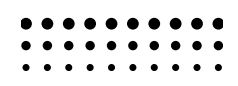

\title{
A Proven Tactic
}

$\mathrm{D}$

ilemma actions can also be referred to as dilemma decisions or dilemma demonstrations, depending on the specific action the group chooses. Regardless of which version you employ, the common denominator is the goal of putting your opponent between a rock and a hard place. I know from experience that dilemma actions, if tailored correctly to the context and conducted well, succeed. I've done it. I've seen it. I've taught others how to do it.

And I'm not alone.

Other activists have written accounts of these types of actions, including George Lakey, whose Powerful Peacemaking: A Strategy for a Living Revolution offered an early account of "dilemma demonstrations" back in 1973. ${ }^{27}$ Philippe Duhamel, a Canadian activist, explains that he devised what he calls a dilemma demonstration after reading Lackey's work. Duhamel's The Dilemma Demonstration: Using 
Nonviolent Civil Disobedience to Put the Government between a Rock and a Hard Place presents a series of effective components to a dilemma demonstration. ${ }^{28}$ Yet while the practice of dilemma actions may have a storied history, we haven't tried learning from them for very long. If we are going to promote dilemma actions as an effective and productive tactic for advancing democracy, we should know what we are doing, right?

Scholars have begun to assess the strengths, risks, core components, and success rates of dilemma actions. We are currently engaged in a major quantitative study of the effects of dilemma actions, and we offer some primary results here.

\section{Our Research Results}

he forty-four cases our team researched come from five
continents and encompass the years 1930-2019. Almost half of our selected cases include elements of humor (laughtivism) as a key part of their dilemma action's strategic framework. Because we wanted to explore dilemma actions in different contexts and environments, we chose cases that covered a wide array of issues, ranging from basic human rights (e.g., freedom of speech and assembly), prodemocracy struggles, and activism for gender and social equality, as well as struggles against corruption and for self-determination. We also wanted to look at diverse political and democratic 
contexts for dilemma action tactics. So, in addition to many brilliant examples of dilemma activism that operated in hostile environments and challenged well-known autocrats, we also examined several recent cases where dilemma actions tackled issues of racial disparity, economic equality, and immigrant rights in the countries largely considered to be democracies, such as the United States and Europe.

In the appendix, you will find the full list of cases we used for this preliminary study organized by date. We used a binary metric to measure the categories for each case. We applied a set of nine questions for each case to determine the success of each question, allowing us to categorize the outcome as, "Yes, it did succeed," "No, it did not succeed," or, "N/A, to indicate unknown." The questions applied for this preliminary study are the following:

- Did it attract media attention? ${ }^{29}$

- Did it reduce fear and apathy among activists?

- Did it attract more supporters?

- Did it reduce risk of severe punishment to activists, or in cases of an oppressive response by authority, make the punishment backfire? ${ }^{30}$

- Did it allow activists to reframe the opponent's narrative, changing their image from "powerful or scary" to "laughable or vincible?"

- Was the action later replicated and spread across constituencies or geography? 
- Was there an international reaction?

- Were there resignations or public excuses from target officials or institutions?

- Did it involve elements of "laughtivism?"

Overall, we found a remarkable degree of success, as shown in table 1.

Table 1: Preliminary assessment of the effects of dilemma actions

\begin{tabular}{lll}
\hline Question & All cases & Laughtivism only \\
\hline $\begin{array}{l}\text { Did the dilemma action attract media } \\
\text { attention? }\end{array}$ & $98 \%$ & $100 \%$ \\
\hline $\begin{array}{l}\text { Did it reduce fear and apathy among } \\
\text { activists? }\end{array}$ & $80 \%$ & $80 \%$ \\
\hline $\begin{array}{l}\text { Did it reduce risk of severe punishment } \\
\text { to activists, and in case of oppressive } \\
\text { answer, make it backfire? }\end{array}$ & $60 \%$ \\
\hline $\begin{array}{l}\text { Did it attract more supporters? } \\
\text { Did it allow activists to reframe the }\end{array}$ & $58 \%$ & $67 \%$ \\
$\begin{array}{l}\text { narrative of the opponent-from } \\
\text { "powerful" or "scary" to "laughable or } \\
\text { vincible?" }\end{array}$ & $81 \%$ \\
\hline $\begin{array}{l}\text { Was it later replicated and spread } \\
\text { across constituencies or geography? }\end{array}$ & $74 \%$ & $75 \%$ \\
\hline \begin{tabular}{l} 
Was there an international reaction? \\
\hline $\begin{array}{l}\text { Was there resignation or public excuses } \\
\text { from target officials or institutions? }\end{array}$
\end{tabular} & $45 \%$ & $38 \%$ \\
\hline $\begin{array}{l}\text { Did it involve elements of } \\
\text { "laughtivism"? }\end{array}$ & $48 \%$ \\
\hline
\end{tabular}


It's important to say, the numbers above are early research-but they are promising. They begin to tell us some things we want to know and also raise some good questions for activists who are considering their next move. For instance, why would laughtivism be less likely to attract new supporters, if it results in more media attention? We'll get to that in a minute. Suffice to say here, though, that these early results must be qualified by our relatively small sample size. Also, our media coverage numbers (98 percent of all cases we looked at!) probably suffer from a sampling bias: that is, we know about the action because it was reported. There are many other less-well-covered actions we are excited to study, and we will do so in future research.

Now, on to the results. One important finding is that the study corroborates the kinds of success that you have heard about or experienced yourself when using these tactics. We find alignment between subjective and object realities, and that's good.

Among the forty-four dilemma actions we studied, 80 percent resulted in a reduction of fear and apathy among activists, 60 percent reduced the risk of severe punishment, and 98 percent attracted substantial media attention. Around 81 percent of the cases attracted more members; 58 percent of them effectively reframed the narrative; and 74 percent were successively replicated. On those metrics that seemed to indicate less favorability for dilemma actions, such as the fact that 49 percent provoked an international reaction and 
43 percent resulted in concessions by target officials, those numbers still represent significant success. In fact, they demonstrate a success rate that outpaces violent resistance success rates (which are 23 percent) by a ratio of almost two to one. ${ }^{31}$

Now, what about laughtivism? On many measures, laughtivism and dilemma actions overall have similar results, and laughtivism was highly successful in general. All twenty-one laughtivism cases drew substantial media attention. Eighty percent of them reduced fear among activists, and 60 percent reduced the risk of punishment-numbers identical to dilemma actions overall. What we found most interesting were those metrics where laughtivism and nonhumorous dilemma actions diverge. What we found, and what conforms to anecdotal experience, is that laughtivism is extremely successful at reframing the narrative (81 percent success versus 58 percent for all cases), even if it might be a little less successful at attracting new members (67 percent versus 81 percent for all cases).

This makes sense. Spectators to laughtivism might participate in a public prank but not feel that they can easily join the movement. Maybe they are more introverted or don't think they have a good sense of humor, or they perceive the activist group to be closed. (Or they fear that the target authority might lash out because it's being mocked.) But because laughtivism uses critical irony to reveal the situational irony of repression, it is extremely good at changing how the public thinks.

For example, when the Indivisible campaign, a response to the election of Donald Trump, decided to highlight the lack 
of congressional accountability to constituents, they devised a brilliant plan to hold town meetings where missing representatives were depicted by empty suits, cardboard cutouts, and in one case, a chicken. This tactic made it incredibly clear to the public that their political representatives were out of touch. It used the irony of representing politicians as missing to underscore the irony that their elected officials were too "busy" or "scared" to talk to voters. This is also a good example of a tactic that did draw more members-possibly because the tactics felt easy for anyone to employ. If activists were dressed as clowns, in other words, the more performative nature of the action might cause many would-be activists to shy away from the thought of putting on a crazy wig and red nose. (The clowns in other actions, however, were great at reframing the narrative and being replicated by other activists already in the cause.)

Finally, bear one more thing in mind. Dilemma actions are a piece of a bigger picture: a spark that takes a movement to another level, or else a single tactic used by an established group. Isolating these tactics, as we've done, does not account for times when international attention or concessions were granted to a movement at a later date or in response to the ways that the dilemma action helped a group increase its visibility and membership. It's hard to fully capture all the ways that the dilemma action might help a group increase its visibility and membership, and our research is just beginning. 